\title{
Phytotoxicological assessment and its relationship with environmental variables of Rio Grande Reservoir waters (São Paulo State, Brazil)
}

\author{
Avaliação fitotoxicológica e sua relação com variáveis ambientais das águas \\ do reservatório Rio Grande (São Paulo, Brasil)
}

\author{
Thais de Araujo Goya Peduto' \\ Tatiane Araujo de Jesus" \\ Lúcia Helena Gomes Coelho"I \\ Werner Siegfried Hanisch ${ }^{\text {IV }}$ \\ Mercia Regina Domingues Morettov \\ Roseli Frederigi Benassi ${ }^{\text {VI }}$
}

\begin{abstract}
Environmental monitoring indicators guide the decision-making process of public policies. Bioassays using seeds are a potential tool to evaluate water quality indicators, since their results can be expressed in a phytotoxicity scale, the tests are quite simple, relatively fast, and low cost. In this context, the objectives of this study were to evaluate the phytotoxicity of Rio Grande reservoir waters and its relationship with environmental variables. In Brazil, this reservoir is an important water source for the public supply of the Metropolitan Region of São Paulo. In 2018, subsurface and bottom water were collected in four sampling campaigns. The environmental variables were measured both in field and at the laboratory. In field, it was used a multiprobe of ammonium $\left(\mathrm{N}-\mathrm{NH}_{4}{ }^{+}\right)$, electrical conductivity $(\mathrm{EC})$, nitrate $\left(\mathrm{N}-\mathrm{NO}_{3}{ }^{-}\right), \mathrm{pH}$, dissolved oxygen (DO) and water temperature (T); and, at the laboratory, of total nitrogen (TN) and total phosphorus (TP). Bioassays using seeds of cucumber (Cucumis sativus), garden cress (Lepidium sativum), and mustard (Sinapis alba) were performed ( $\mathrm{n}$ $=6)$. The bioassays consisted of incubating the seeds and the water samples on Petri dishes at $\left(20^{\circ} \pm 2{ }^{\circ} \mathrm{C}\right)$ in the absence of light for 3 days, in case of $S$. alba, and for 4 days, in case of $C$. sativus and L. sativum. ISO water was used as a control. Afterward, the number of germinated seeds and the roots' length were determined to calculate the Germination Index $(\mathrm{Gl})$. Statistical analyses were performed, such as the Shapiro-Wilk test, the analysis of variance (ANOVA) and the Tukey test, to verify the differences between the seeds' responses to the environmental variables. The Principal Component Analysis (PCA) was applied to the environmental variables and the GI to identify the most representative variables. This study indicated that, in May of 2018, the subsurface water was moderately phytotoxic to $L$. sativum $(G I=61.3 \pm 8.2 \%)$; and the bottom water was very phytotoxic to $L$. sativum $(G I=23.6 \pm 14.5 \%)$ and $S$. alba $(26.2 \pm 12.0 \%)$. In all other sampling campaigns, the water samples potentiated seed germination, which can be related to nutrients concentrations The $L$. sativum proved to be more sensitive, due to the lower degrees of data dispersion and the higher degrees of toxicity when compared to the other analyzed seeds.
\end{abstract}

Keywords: Bioassays; Environmental monitoring; Eutrophication; Seeds germination; Water quality.

\footnotetext{
'Universidade Federal do ABC, Santo André, SP, Brazil - thais.goya@ufabc.edu.br.

"Universidade Federal do ABC, Santo André, SP, Brazil - tatiane.jesus@ufabc.edu.br.

III Universidade Federal do ABC, Santo André, SP, Brazil - lucia.coelho@ufabc.edu.br.

IV Universidade Federal de São Paulo, São Paulo, SP, Brazil - werner.hanisch@unifesp.br.

${ }$ Universidade Federal do ABC, Santo André, SP, Brazil-mercia.domingues@ufabc.edu.br.

VI Universidade Federal do ABC, Santo André, SP, Brazil - roseli.benassi@ufabc.edu.br.
} 


\section{Resumo}

Os indicadores de monitoramento ambiental norteiam o processo de tomada de decisão de políticas públicas. Bioensaios com sementes são ferramentas potenciais como indicadores de qualidade da água, pois seus resultados podem ser expressos em uma escala de fitotoxicidade, os testes são bastante simples, relativamente rápidos e de baixo custo. Nesse contexto, os objetivos deste estudo foram: avaliar a fitotoxicidade das águas do reservatório do Rio Grande e sua relação com as variáveis ambientais. Este reservatório é uma importante fonte de água para a Região Metropolitana de São Paulo no Brasil. Água subsuperficial e de fundo foram coletadas em quatro campanhas de amostragem em 2018. As variáveis ambientais foram medidas em campo usando uma multi-sonda: amônio $\left(\mathrm{N}-\mathrm{NH}_{4}{ }^{+}\right)$, condutividade elétrica $(\mathrm{CE})$, nitrato $\left(\mathrm{N}-\mathrm{NO}_{3}{ }^{-}\right)$, $\mathrm{pH}$, oxigênio dissolvido (OD) e temperatura da água (T); e no laboratório: nitrogênio total (NT) e fósforo total (PT). Foram realizados bioensaios com sementes de pepino (Cucumis sativus), agrião (Lepidium sativum) e mostarda (Sinapis alba) $(n=6)$. Os bioensaios consistiram em incubar as sementes e amostras de água em placas de Petri a $\left(20^{\circ} \pm 2^{\circ} \mathrm{C}\right.$ ) na ausência de luz por 3 dias (S. alba) e 4 dias (C. sativus e L. sativum). Água ISO foi usada como controle positivo. Na sequência foram determinados o número de sementes germinadas e o comprimento das raízes para cálculo do Índice de Germinação (IG). Foram realizadas análises estatísticas, como o teste de Shapiro-Wilk, análise de variância (ANOVA) e teste de Tukey para verificar as diferenças entre as respostas das sementes às variáveis ambientais. A Análise de Componentes Principais (ACP) foi aplicada às variáveis ambientais e IG para identificar as variáveis mais representativas. $O$ estudo indicou que em maio de 2018 a água subterrânea era moderadamente fitotóxica para $L$. sativum (IG $=61,3 \pm 8,2 \%$ ); e a água do fundo foi muito fitotóxica para L. sativum (IG $=23,6 \pm 14,5 \%)$ e $S$. alba $(26,2 \pm 12,0 \%)$. Em todas as demais campanhas de amostragem, as amostras de água potencializaram a germinação das sementes, o que pode estar relacionado à concentração de nutrientes. A espécie L. sativum mostrou-se mais sensível, devido ao menor grau de dispersão dos dados e ao maior grau de toxicidade em relação às demais sementes analisadas.

Palavras-Chave: Bioensaios; Eutrofização; Germinação de sementes; Monitoramento ambiental; Qualidade da água.

\section{Introduction}

Eutrophication is defined by the excessive increase in the biomass of primary producers and it is triggered by the nutritional enrichment of the aquatic environment (Jeppesen et al., 2017). Human actions are directly related to the eutrophication increase of continental aquatic ecosystems (Brasil, 2015).

The harmful consequences to the aquatic environment are: alteration of the phytoplankton community; accumulation of organic matter from algae and aquatic macrophyte biomass; depletion of dissolved oxygen concentration; presence of unpleasant odour and taste in the water; landscape degradation; biodiversity reduction; the intrinsic toxic potential of cyanobacteria presence in blooms, which is relevant when it comes to a public supply reservoir (Beghelli et al., 2015; Brasil, 2015). 
The discharge of domestic and industrial raw sewage, or those treated only at the secondary level and are rich in organic matter and nutrients, causes changes in the functioning of the ecosystem with ecological, economic, and social consequences (LópezDoval et al., 2017). In addition, the urban wastewater may contain high concentrations of metals such as zinc, copper, arsenic, lead, nickel, antimony, selenium; amongst organic pollutants and organochlorine compounds (Vieira, 2017) which, in high concentrations, are toxic to plants and organisms in the water body.

Human activities in the hydrographic basin result in changes in the water body (Maia et al., 2015). Yet, according to Pickett et al. (2011), by 2030, approximately $60 \%$ of the world population must live in urbanized areas. This fact can result in a more intense disturbance of the aquatic environments in the densely occupied metropolitan regions. The Rio Grande reservoir is an isolated branch of the Billings complex which receives wastewater discharges due to irregular occupations in its surroundings (Capobianco and Whately, 2002), tributary dumps with a characteristic of domestic and industrial sewage (Mariani and Pompêo, 2008), high levels of hormones and total phosphorus (Coelho et al., 2020) and application of algaecide (e.g.: $\mathrm{CuSO}_{4}$ and $\mathrm{H}_{2} \mathrm{O}_{2}$ ) in the vicinity of the water catchment (Cunha et al., 2013; Franklin et al., 2015; Pompêo, 2017). The Sanitation Company applies algicides compounds directly in the reservoir surface to stop the algae proliferation, since algae cells can clog the sand filters of Water Treatment Plants, as well as alter its organoleptic properties (Doederer, Gale and Keller, 2019).

Environmental monitoring indicators emerge as a result of the growing concern with environmental aspects, and they assist in the decision-making process of public policies with regular monitoring of water bodies which are important to develop and apply efficient management strategies (Meerssche and Pinckney, 2019). One of the possibilities for monitoring is ecotoxicological tests which aim to predict and understand whether the contaminants' effects are likely to cause damage to organisms exposed to toxic agents (Silva and Mattiolo, 2011). The tests were carried out with aquatic species, such as the Daphnia magna, the Desmodesmus subspicatus and the Hyalella azteca, which are widely used in scientific studies (Paula, 2016; Cervi et al., 2019), and regulated by the competent agencies 
as parameters of water quality, sediments and effluents (Brasil, 2004; CETESB, 2017). National agencies, such as the Brazilian Technical Standards Association (ABNT) and the Environmental Company of the State of São Paulo (CETESB); and the international agencies, such as the United States Environmental Protection Agency (USEPA), the Environment Canada, the Environment Ontario, and the American Society for Testing Materials (ASTM) standardize these tests by pointing out their variation between acute and chronic. The advantages of the acute tests are the quantification and qualification of the disturbance degree caused by the pollutants, their reproducibility, and their short period; while the chronic tests have more sensitive responses, such as the damage to deoxyribonucleic acid (DNA) and the inhibition of enzymes (Paula, 2016).

Ecotoxicity tests can also be performed with plant indicators and they are widely used in scientific studies (Belo, 2011; Cruz et al., 2013; Lapa, 2014; Kohatsu et al., 2018; Porto et al., 2019; Coelho et al., 2020) due to their simplicity and low costs (Peduto et al., 2019). The seed bioassays aim to determine if there is a change in seedling germination, by indicating the toxicity degree of the sample. Plant development requires some essential chemical elements, called micronutrients and macronutrients (Porto et al., 2019). In Brazil, toxicity tests based on plant indicators are not yet accepted as parameters for the quality of the water or sediments. The Brazilian Ministry of Agriculture, Livestock and Supply regulates, for agricultural purposes, germination tests, which are normally adopted as a basis for the preparation of phytotoxicity tests (Brasil, 2009). In scientific terms, the species of seeds and the samples analysed are quite variable (Fantin et al., 2009; Emami et al., 2014; Zhang et al., 2018; Coelho et al., 2020; Matsubara et al., 2020).

Mendes et al. (2020) evaluated variations in temperature, sample volume and plate size in bioassays with lettuce seeds (Lactuca sativa) and found a difference between these methods, recommending in-depth knowledge about the use of seeds as bioindicators. Tests with L. sativa, for different nanoparticle treatments, showed that the $\mathrm{CuSO}_{4}$ samples associated with $\mathrm{N}-\mathrm{NH}_{4}{ }^{+}$synthesis had a low germination rate, with highly phytotoxic values; and the $\mathrm{ZnSO}_{4}$ samples did not germinated (Porto et al., 2019). Ovsyannikova and Pryanichnikova (2019) adopted the species Lepidium sativum in the comparative assessment 
of the water ecotoxicity in oil samples, and they concluded that organic substances, such as the petroleum hydrocarbons, caused toxicity in the samples. Inhibition of seed root growth and a strong correlation among the germination index (GI), the electrical conductivity (EC) and the total dissolved solids (TDS) were observed in bioassays with Sinapis alba testing water samples from affluents of the Rio Grande Reservoir (Kohatsu et al., 2018). The efficiency of the Cucumis sativus seeds in bioassays was tested using two toxic compounds - $\mathrm{Al}_{2}\left(\mathrm{SO}_{4}\right)_{3}$ and Methyl Methanesulfonate (MMS) solution -, concluding that it is feasible to use the seeds as a model in the phytotoxicity biotests, presenting some sensitivity to the toxicity of compounds with reduced root growth (Barbosa et al., 2013). Extracts of various materials, which are routinely used in composting, presented a moderate toxicity (rice husk) and high phytotoxicity (chicken residues, fly ash, wheat straw and sawdust) in bioassays with L. sativum; however, vegetation cuttings and sludge from Wastewater Treatment Plants (WWTP) did not present any toxicity (Belo, 2011).

Thus, as the seed bioassays have a relatively quick response, low cost and enable inferring about the toxicity of environmental samples; they should be further studied in order to create standardized protocols and evaluate their inclusion as an additional line of evidence in the monitoring of water and sediment quality. Finally, the objectives of this study were: (1) to evaluate the waters phytotoxicity of an urban reservoir used for public supply purposes, through bioassays with seeds of: cucumber (Cucumis sativus), garden cress (Lepidium sativum) and mustard (Sinapis alba); (2) to identify possible correlations between environmental parameters and the bioassays with seeds, raising the hypothesis that these tests can be adopted as a parameter of water quality and, thus, contribute to public policies of environmental management and monitoring.

\section{Material and Methods}

\subsection{Study area}

The study was conducted with water samples collected in the Rio Grande reservoir (Figure 1), located in the southeast of São Paulo state, Brazil. This reservoir is classified in 
Class II of the Resolution 357 from Brazilian National Environment Council (CONAMA). So, these waters can be used for public supply purposes after conventional treatment and their quality should be maintained in accordance with what was determined in this document (Brasil, 2005).

Figure 1 - Study area location: (a) São Paulo State in Brazil; (b) Metropolitan Area of São Paulo (MASP) in São Paulo State; (c) Billings Reservoir location in MASP; (d) Rio Grande and Billings Reservoirs, and (e) sampling station on the Rio Grande Reservoir

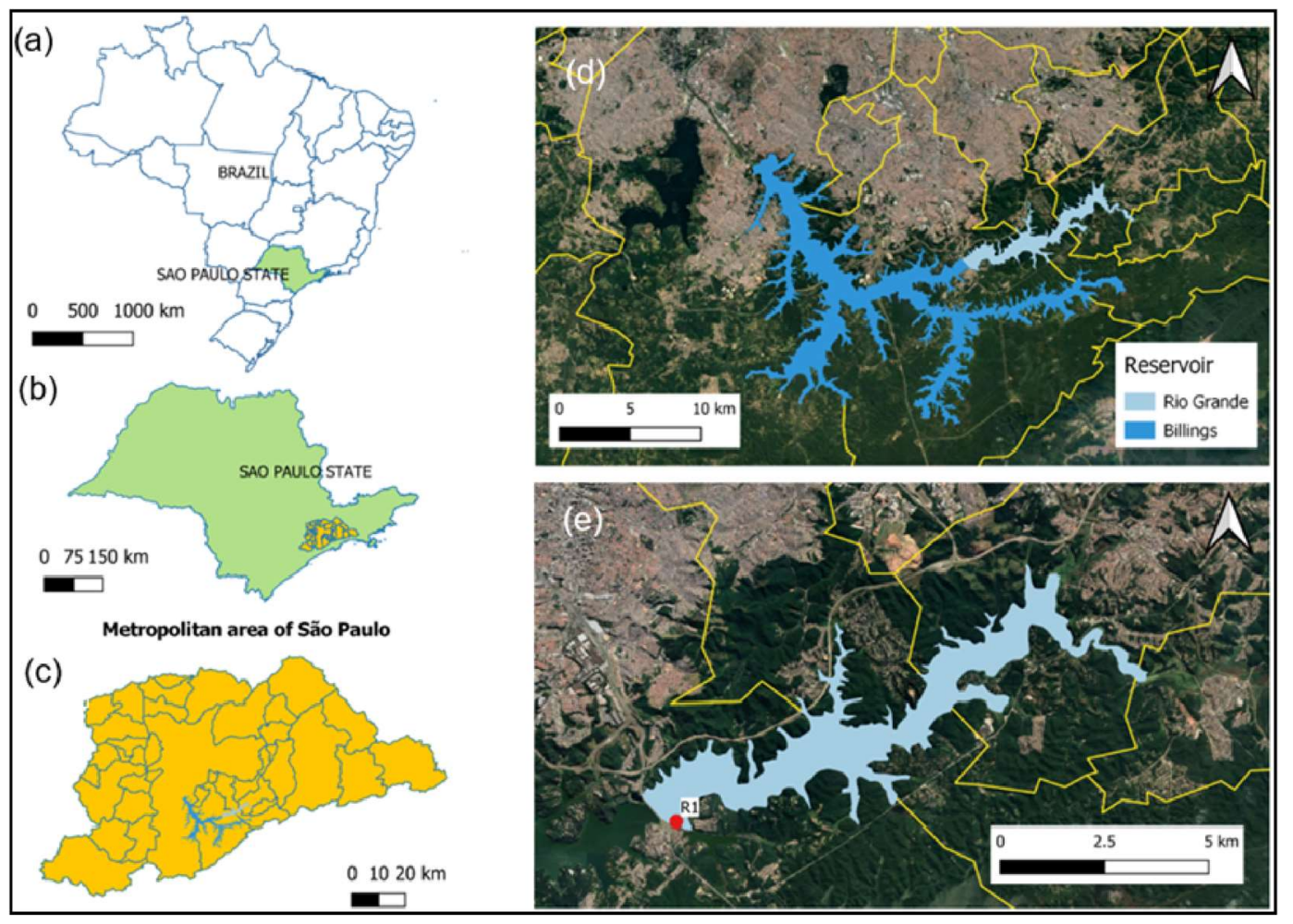

Source: Map data @ 2015 Google.

Four sampling campaigns were carried out in 2018, one in each of the following months: February, May, August and September. The sampling station is located close to the water abstraction of the local Sanitation Company. The rainfall $(\mathrm{mm})$ and active capacity $\left(\mathrm{hm}^{3}\right)$ data were obtained in Sabesp (2020). The environmental variables, such as ammonium $\left(\mathrm{N}-\mathrm{NH}_{4}{ }^{+}\right)$, electrical conductivity (EC), nitrate $\left(\mathrm{N}-\mathrm{NO}_{3}{ }^{-}\right), \mathrm{pH}$, dissolved oxygen (DO) and water temperature $(T)$, were determined in situ with a multiparametric probe (Brand: Hach Hydrolab, model: DS5X). The levels of total nitrogen (TN) and total phosphorus (TP) were determined according to the Method 4500N C - Persulfate digestion -, the Method 
4500Norg - Titulometric (APHA, 2005) and Spectrophotometric -, and the Method 4500P B - Persulfate digestion (APHA, 2005). These analyses were performed in triplicates.

The bioassays with seeds of cucumber (Cucumis sativus), garden cress (Lepidium sativum), and mustard (Sinapis alba) were performed in six replicates. The bioassays consisted in covering a $9 \mathrm{~cm}$ diameter Petri dish with qualitative paper substrate; applying $3 \mathrm{~mL}$ of sample; arranging 6 seeds of each species in a straight line with uniform and sufficient spacing to minimize competition between the seeds germination; and wrapping the plate with a plastic film to maintain the moisture. International Organization for Standardization (ISO) water was used as a control and it was prepared following the OECD (2004): calcium chloride $\left(1.18 \mathrm{mg} \mathrm{L}^{-1}\right)$, magnesium sulphate $\left(0.50 \mathrm{mg} \mathrm{L}^{-1}\right)$, sodium bicarbonate $\left(0.26 \mathrm{mg} \mathrm{L}^{-1}\right)$ and potassium chloride $\left(0.02 \mathrm{mg} \mathrm{L}^{-1}\right)$ in their respective quantities; added to $1,000 \mathrm{~mL}$ of distilled water; and stirred until the substances are fully diluted - valid for 3 months after preparation.

The proposed tests are known as vigour tests and the seeds must germinate in the initial incubation period, it being 4 days for the species $C$. sativus and L. sativum, and 3 days for the S. alba (Brasil, 2009), under the temperature of $\left(20 \pm 2^{\circ} \mathrm{C}\right)$ in the absence of light in a greenhouse $(n=6)$. After the incubation, it was visually analysed if there was a germination; and if positive, it was analysed if the seed roots growth showed a certain degree of toxicity, such as an irregular growth and a gray or dark colour.

The length of the germinated roots was measured with the aid of a digital caliper $(150 \pm 0.01 \mathrm{~mm})$ and the percentage of absolute germination rate (\% AG, Equation 1), the percentage of average root growth (\% ARG, Equation 2) and the germination index (Gl, Equation 3. The classification that determines the degree of toxicity present in the sample can be done through several indexes found in the literature. In this study, a classification of the germination index provided by Belo (2011) was adopted where: <30, very phytotoxic; 30-60, phytotoxic; 60-80, moderately phytotoxic; 80-100, non-phytotoxic; and $>100$ potentiates germination.

$$
\% A G=(S \text { germinated_sample }) /(S \text { germinated_control }) * 100
$$




$$
\begin{aligned}
& \% A R G=\left(L^{=} \text {radicle_sample }\right) /\left(L^{=} \text {radicle_control }\right) * 100 \\
& G I(\%)=(\% A G * \% A R G) / 100
\end{aligned}
$$

Where "S germinated_sample" is the arithmetic mean of the number of seeds germinated in the sample; " $\mathrm{S}$ germinated_control" is the arithmetic mean of the number of seeds germinated in the control; "L" radicle_sample" is the arithmetic mean of the length of the sample's radicles; " $L$ "radicle_control" is the arithmetic mean of the radicle length of the control.

To verify if the data fits to the normal distribution, the Shapiro-Wilk test with $p$ value $>0.05$ was adopted. The statistical analysis adopted to verify if there is a significant difference between the seed species was the analysis of variance (ANOVA) $(p<0.05)$, followed by the Tukey test, all in the Past ${ }^{\circledR}$ software version 4.02, with free license. The null hypothesis was that the species are the same, and the alternative hypothesis was that at least one species is significantly different. The principal component analysis (PCA) was applied to the samples' environmental and GI variables to identify the most representative variables, using OriginPro ${ }^{\circledR}$ software version 9.6.5.169, 2019, with a license acquired for UFABC.

\section{Results and Discussion}

In Table 1, the rainfall data indicated that only on February 21, 2018 - the date before the first collection -, there was a $1.4 \mathrm{~mm}$ rainfall in the reservoir. The volume of the dam had an average value between collections $\left(92.9 \mathrm{hm}^{3}\right)$, highlighting the measurement of $08 / 21 / 2018$ (referring to the $3^{\text {rd }}$ collection) at the lowest value, $86.4 \mathrm{hm}^{3}$. The precipitation in the hydrographic basins that form the reservoir can directly affect the availability of nutrients, as it carries impurities to the bodies of water (Burgos et al., 2015). The table 1 presents the results of the environmental variables and the GI for subsurface and bottom waters. 
In February 2018, high concentrations of $\mathrm{N}-\mathrm{NH}_{4}{ }^{+}\left(16.9 \pm 1.5 \mathrm{mg} \mathrm{L}^{-1}\right), \mathrm{N}-\mathrm{NO}_{3}{ }^{-}(4.6 \pm$ $\left.0.2 \mathrm{mg} \mathrm{L}^{-1}\right)$, TN $\left(2.9 \pm 1.7 \mathrm{mg} \mathrm{L}^{-1}\right)$ stood out and $\mathrm{pH}(7.8 \pm 0.1)$ in subsurface waters, following the same pattern in bottom waters, $N-N_{4}{ }^{+}\left(24.9 \pm 0.1 \mathrm{mg} \mathrm{L}^{-1}\right), \mathrm{N}-\mathrm{NO}_{3}^{-}\left(4.6 \pm 0.2 \mathrm{mg} \mathrm{L}^{-1}\right)$, $\mathrm{TN}\left(2.3 \pm 2.0 \mathrm{mg} \mathrm{L}^{-1}\right)$ and $\mathrm{pH}(6.9 \pm 0.1)$. 
Table 1 - Pluviometric index $(\mathrm{mm})$ and Rio Grande Reservoir volume $\left(\mathrm{hm}^{3}\right)$ in the last and in the sampling day (Source: Sabesp, 2020). Environmental variables $(n=3)$ and Germination Index $(\mathrm{Gl})(n=6)$ from surface and bottom water. $\mathrm{Gl}$ is represented according to seed species: GIGC (L. sativum, garden cress), GIM (S. alba, mustard) and GIC (C. sativus, cucumber). Bold values disagree to Brazilian legislation (Brasil, 2005) ${ }^{1}$. (*missing value)

\begin{tabular}{|c|c|c|c|c|c|}
\hline & \multirow{2}{*}{ Variable } & \multicolumn{4}{|c|}{ Sampling campaigns in 2018} \\
\hline & & February & May & August & November \\
\hline \multirow{2}{*}{$\begin{array}{c}\text { Rainfall } \\
\text { index (mm) }\end{array}$} & Last day & 1.4 & 0.0 & 0.0 & 0.0 \\
\hline & In day & 0.0 & 0.0 & 0.0 & 0.0 \\
\hline \multirow{2}{*}{$\begin{array}{c}\text { Reservoir } \\
\text { volume } \\
\left(\mathrm{hm}^{3}\right)\end{array}$} & Last day & 94.42 & 98.07 & 86.38 & 93.05 \\
\hline & In day & 94.25 & 97.90 & 86.38 & 93.05 \\
\hline \multirow{11}{*}{$\begin{array}{c}\text { Surface } \\
\text { water }\end{array}$} & $\mathrm{pH}$ & $7.8 \pm 0.1$ & $8.1 \pm 0.0$ & $12.5 \pm 0.0$ & $8.6 \pm 0.1$ \\
\hline & $\mathrm{T}\left({ }^{\circ} \mathrm{C}\right)$ & $24.2 \pm 0.2$ & $24.6 \pm 0.1$ & $19.6 \pm 0.0$ & $22.7 \pm 0.0$ \\
\hline & $\mathrm{EC}\left(\mu \mathrm{S} \mathrm{cm}^{-1}\right)$ & $98.4 \pm 0.0$ & $92.7 \pm 3.4$ & $97.0 \pm 0.0$ & $106.0 \pm 1.7$ \\
\hline & $\mathrm{DO}\left(\mathrm{mg} \mathrm{L}^{-1}\right)$ & $6.3 \pm 0.0$ & $8.6 \pm 0.1$ & $9.2 \pm 0.0$ & $8.4 \pm 0.0$ \\
\hline & $\mathrm{N}-\mathrm{NO}_{3}^{-}\left(\mathrm{mg} \mathrm{L}^{-1}\right)$ & $4.6 \pm 0.2$ & $0.7 \pm 0.0$ & $1.5 \pm 0.0$ & $1.5 \pm 0.2$ \\
\hline & $\mathrm{N}-\mathrm{NH}_{4}{ }^{+}\left(\mathrm{mg} \mathrm{L}^{-1}\right)$ & $16.9 \pm 1.5$ & $0.2 \pm 0.0$ & $0.4 \pm 0.0$ & $0.2 \pm 0.0$ \\
\hline & $\mathrm{TN}\left(\mathrm{mg} \mathrm{L}^{-1}\right)$ & $2.9 \pm 1.7$ & $2.2 \pm 0.9$ & $0.7 \pm 0.0$ & * \\
\hline & $\mathrm{TP}\left(\mu \mathrm{g} \mathrm{L}^{-1}\right)$ & $22.7 \pm 3.6$ & $25.7 \pm 2.1$ & $27.0 \pm 10.0$ & $16.3 \pm 5.8$ \\
\hline & GIGC (\%) & $124.7 \pm 3.6$ & $61.3 \pm 8.2$ & $89.5 \pm 17.0$ & $106.9 \pm 23.9$ \\
\hline & GIM (\%) & $123.4 \pm 78.7$ & $102.0 \pm 29.6$ & $162.4 \pm 26.5$ & $116.9 \pm 19.5$ \\
\hline & GIC (\%) & $104.8 \pm 59.5$ & $114.2 \pm 17.1$ & $145.1 \pm 27.0$ & $143.4 \pm 20.2$ \\
\hline \multirow{11}{*}{$\begin{array}{l}\text { Bottom } \\
\text { water }\end{array}$} & $\mathrm{pH}$ & $6.9 \pm 0.1$ & $7.5 \pm 0.0$ & $12.6 \pm 0.0$ & $8.6 \pm 0.0$ \\
\hline & $\mathrm{T}\left({ }^{\circ} \mathrm{C}\right)$ & $23.0 \pm 0.0$ & $23.8 \pm 0.0$ & $18.4 \pm 0.0$ & $22.6 \pm 0.0$ \\
\hline & $\mathrm{EC}\left(\mu \mathrm{S} \mathrm{cm}^{-1}\right)$ & $102.6 \pm 0.5$ & $90.2 \pm 0.1$ & $94.5 \pm 2.1$ & $106.0 \pm 0.0$ \\
\hline & $\mathrm{DO}\left(\mathrm{mg} \mathrm{L}^{-1}\right)$ & $0.3 \pm 0.1$ & $7.8 \pm 0.0$ & $8.9 \pm 0.0$ & $4.5 \pm 0.5$ \\
\hline & $\mathrm{N}-\mathrm{NO}_{3}^{-}\left(\mathrm{mg} \mathrm{L}^{-1}\right)$ & $4.2 \pm 0.0$ & $0.5 \pm 0.0$ & $1.0 \pm 0.0$ & $1.0 \pm 0.1$ \\
\hline & $\mathrm{N}-\mathrm{NH}_{4}{ }^{+}\left(\mathrm{mg} \mathrm{L}^{-1}\right)$ & $24.9 \pm 0.1$ & $0.4 \pm 0.0$ & $0.5 \pm 0.0$ & $0.3 \pm 0.0$ \\
\hline & $\mathrm{TN}\left(\mathrm{mg} \mathrm{L}^{-1}\right)$ & $2.3 \pm 2.0$ & $1.2 \pm 0.1$ & $1.0 \pm 0.1$ & * \\
\hline & $\mathrm{TP}\left(\mu \mathrm{g} \mathrm{L}^{-1}\right)$ & $63.9 \pm 14.7$ & $35.4 \pm 0.0$ & $57.0 \pm 0.0$ & $33.0 \pm 0.0$ \\
\hline & GIGC (\%) & $89.2 \pm 14.0$ & $23.6 \pm 14.5$ & $101.0 \pm 20.4$ & $126.6 \pm 6.9$ \\
\hline & GIM (\%) & $171.4 \pm 39.6$ & $26.2 \pm 12.0$ & $181.8 \pm 36.8$ & $129.3 \pm 28.9$ \\
\hline & GIC (\%) & $166.5 \pm 18.6$ & $116.2 \pm 45.9$ & $169.5 \pm 22.1$ & $127.3 \pm 12.9$ \\
\hline
\end{tabular}

${ }^{1}$ Water quality standard by the guidelines of the CONAMA No $357 / 2005$ for bodies of water class II: $\mathrm{pH}$ in 6.0

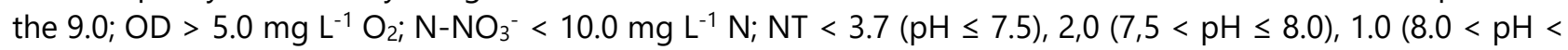
8.5) and $0.5 \mathrm{mg} \mathrm{L}^{-1} \mathrm{~N}(\mathrm{pH} \geq 8.5) ;$ PT $<30 \mu \mathrm{g} \mathrm{L}-1$ PT (Brasil, 2005). 
Barbieri et al. (2014) pointed out in their study that natural environments that received wastewater, industrial waste and pesticides had high concentrations of $\mathrm{N}-\mathrm{NH}_{4}{ }^{+}$. Ammoniacal nitrogen, in large quantities in the waters, indicates that there is a decomposing organic matter (Kindlein, 2010). In our study, the high $\mathrm{N}^{-\mathrm{NH}_{4}}{ }^{+}$content was found only in the sample referring to February 2018, with the other months following an average pattern of $\left(0.4 \pm 0.1 \mathrm{mg} \mathrm{L}^{-1}\right)$. Porto et al. (2019) explain that plant cells convert the ammonium generated by the assimilation of nitrate or photorespiration. Nitrogen, when in excess, is one of the most important contaminants present in wastewater; and the byproduct of its oxidation generates nitrate, which can cause problems related to the toxicity of aquatic flora and fauna, decreasing dissolved oxygen and eutrophication of bodies water resources (Zoppas et al., 2016). With a focus on the plants, the nitrate ion is the only form of nitrogen absorbed by plant species (Kindlein, 2010), making it important to determine the tolerance of plant organisms to this chemical element.

The $\mathrm{pH}$ referring to the August 2018 collection, both in subsurface and deep waters, showed an alkaline character of $(12.5 \pm 0.0)$ and $(12.6 \pm 0.0)$, respectively, higher than the established by the CONAMA Resolution 357/2005 (Brasil, 2005). Mariani and Pompêo (2008) justify the alkaline character of the $\mathrm{pH}$ data found in the Rio Grande dam with the photosynthetic activity that removes $\mathrm{CO}_{2}$ and $\mathrm{HCO}_{3}{ }^{-}$from the water and alters the balance of the carbonate system, resulting in an increase in $\mathrm{pH}$ levels. $\mathrm{CuSO}_{4}$ treatments make the backwaters more acidic due to the copper hydrolysis (Padovesi-Fonseca and Philomeno, 2004), which may be the answer to the acidity found in the waters of February 2018. Still, in February 2018, the waters of background showed a significant decrease in the DO value (0.3 $\pm 0.1 \mathrm{mg} \mathrm{L}^{-1}$ ). Kindlein (2010) justifies that if there are high levels of $\mathrm{N}^{-\mathrm{NO}_{3}}{ }^{-}$in the water, there is a decomposing organic matter or the presence of sewage and the environment is probably low in oxygen, making DO a determining factor in the nitrogen cycle. It is also pointed out that nitrate is one of the forms of nitrogen which assumes great importance in aquatic ecosystems, reaching high waters and deep waters.

Temperature, in turn, is a determining factor in the reactions which alter the physical, chemical and biological processes in the water bodies, and elevated temperatures can 
decrease the amount of dissolved oxygen, putting the water quality at risk if they receive domestic sewage tributaries (Hermes and Silva, 2004). The TP value of bottom waters (63.9 $\left.\pm 14.7 \mu \mathrm{g} \mathrm{L}^{-1}\right)$ was higher than that of subsurface waters $\left(22.7 \pm 3.6 \mu \mathrm{g} \mathrm{L}^{-1}\right)$, in February 2018, pointing out that the proximity to sediments may be related to these values, since there is an accumulation of nutrients and metals in the sediments of the Rio Grande reservoir (Franklin et al., 2015). It is known that sediments have a high potential for accumulation, functioning as a record of environmental information in seasonal and spatial aspects (Franklin, 2010). However, sediment resuspension is not a constant threat, but it is a common one and can be an important stressor for organisms (Cervi et al., 2019). The resuspension acts on the dynamics of nutrients and contaminants that have been stored in the sediment layers of the water body over time, causing negative impacts on the water quality. In shallow reservoirs, this process can be intensified due to the small depth of the water column, as is the case of the Rio Grande reservoir (minimum and maximum depth: $7.5 \sim 9.7 \mathrm{~m}$ between collections). In addition, the resuspension alters the turbidity, since there are materials in suspension reducing the absorption of light (Brito Jr, 2015). Franklin et al. (2015) found sediments extremely enriched with Mercury (Hg), Copper (Cu) and Cadmium $(\mathrm{Cd})$ in the upper layers of the Rio Grande reservoir, and the main reasons for the high concentrations of metals found in the sediments of the Rio Grande reservoir were the release of domestic effluents, and the frequent use of copper sulfate to control algae development and industrial effluent deposits (Bostelmann, 2006). Copper is considered an essential element in the structural development, compound or metabolite of the plant, since it is essential in the flowering and fruiting stage; thus, its deficiency causes the seedling to die and its high concentrations may present toxicity (Porto et al., 2019). Wengrat (2016) carried out a historical paleoenvironmental assessment of eutrophication and natural variability in the Rio Grande reservoir from sediments, and found that, between the years of 1953 and 1982, the reservoir was negatively impacted by anthropic activities, with rapid progress in the eutrophication, presenting high TP values and TN enrichment. The Rio Grande branch was part of the Billings dam, but as of 1982, the dam was completed, separating it and transforming it into the Rio Grande dam. Thereafter, the dam indicated 
improvement in its waters, however, it returned to its eutrophic condition with the upstream urbanization. Although these studies point to data only on sediments, some biotic and abiotic reactions occur in the sediment compartments, reaffirming the importance they have in the water quality (Stumm and Morgan, 1981). Pompêo (2017) compiled data from Cetesb and Sabesp, regarding the application of algaecide in Brazilian reservoirs in the years of 2006, 2007 and 2011; and pointed out that the applications of $\mathrm{CuSO}_{4}$ that occurred in the Rio Grande dam, in the years of 2006 and 2007, were significant, with estimated values of 150 ton/y and 360 ton/y, respectively, and about 40 ton/y of copper sulphate and 300 ton/y of $\mathrm{H}_{2} \mathrm{O}_{2}$ in 2011; highlighting the importance of evaluating the Rio Grande reservoir. The application of algaecides causes the rupture of algal cells, causing the release of metabolites in water, including cyanotoxins (Pompêo, 2017).

As for the AG (\%), the United States Environmental Protection Agency - USEPA (1989) recommends that the $A G(\%)$ must be greater than $65 \%$ of the analyzed seeds, so that the data are reliable. In our results, the species C. sativus, L. sativum and S. alba had a minimum germination percentage of $66.7 \%$ and we can continue with the analysis of the results. As for the $\mathrm{Gl}(\%)$ of the species C. sativus, all values were higher than $100 \%$, indicating that seed germination was enhanced in all collections. The species $L$. sativum showed a toxicity level in the collection carried out in May 2018, both in groundwater $(61.3 \pm 8.2 \%)$ and in bottom water $(23.6 \pm 14.5 \%)$. This species had the lowest degree of dispersion, with the lowest standard deviation values. According to Mendes et al., (2020), the lowest dispersion values of data indices should be preferred. The species S. alba showed similar results, in May 2018, with a significantly toxic value in the bottom waters (26.2 $\pm 12.0 \%$ ). Tiquia (2010) points out that the species L. sativum is more sensitive to the toxicity of soils contaminated with metals than other species of plants. However, the species $S$. alba is from the same botanical family as the L. sativum, "Brassicaceae", pointing out a similar toxicity relationship between these species.

The Shapiro-Wilk normality test showed that the data are normal $(p=0.13)$, and then followed by the ANOVA, which resulted in a value of $p=0.06$ and despite its proximity of the significance value $(\alpha=0.05)$, the test did not reject the null hypothesis at a significance 
level of $5 \%$, pointing out that there is no statistical difference between the species of seeds. As for the PCA for subsurface waters, the first axis - PC1 - accounted for $50.7 \%$ of the variation in the data, and the $\mathrm{PC2}, 27.5 \%$ (Figure $2 \mathrm{a}$ ), totaling $78.2 \%$. For the bottom waters, the PC1 represented $47.4 \%$ and the PC2, 32.9\%, totaling $80.3 \%$ (Figure 2b). The most important variables are those with the highest coefficients and scores, both negative and positive, and they were highlighted in bold in Table 2 .

Figure 2 - Principal Component Analysis of environmental variables and germination index using different seed species (GIGC: L. sativum; GIM: S. alba and GIC: C. sativus) to subsurface and bottom water samples of Rio Grande reservoir

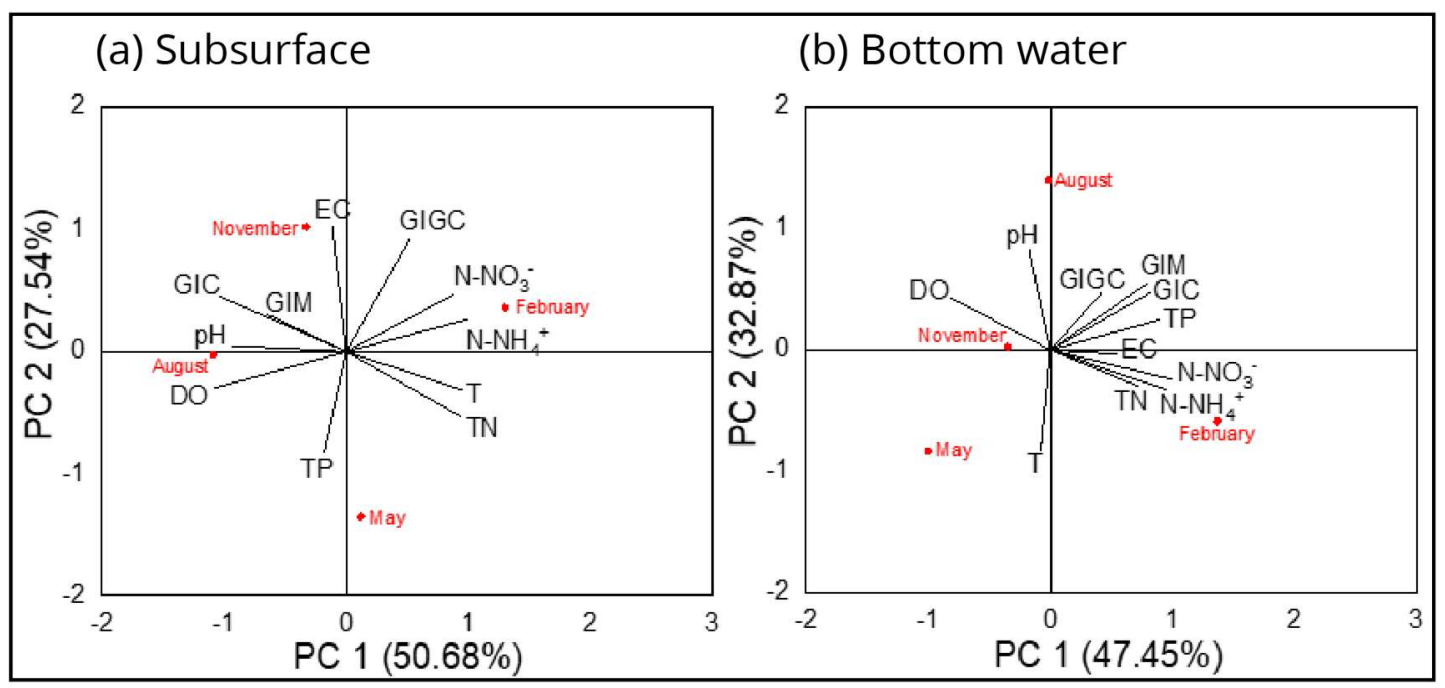


Table 2 - Scores and variances explained by the first two main components of the analysis of the data of the limnological variables of the groundwater and bottom of the Rio Grande reservoir, with the most considered and correlated values in bold

\begin{tabular}{lcccc}
\hline \multirow{2}{*}{ Variable } & \multicolumn{2}{c}{ Subsurface } & \multicolumn{2}{c}{$\begin{array}{c}\text { Bottom } \\
\text { water }\end{array}$} \\
\cline { 2 - 5 } & $\mathbf{P C 1}$ & $\mathbf{P C 2}$ & $\mathbf{P C 1}$ & $\mathbf{P C 2}$ \\
\hline $\mathrm{pH}$ & $\mathbf{- 0 . 3 4}$ & +0.02 & -0.07 & $\mathbf{+ 0 . 5 1}$ \\
$\mathrm{T}$ & $\mathbf{0 . 3 5}$ & -0.16 & -0.03 & $\mathbf{- 0 . 5 1}$ \\
$\mathrm{EC}$ & -0.04 & $\mathbf{+ 0 . 5 3}$ & +0.23 & -0.02 \\
$\mathrm{DO}$ & $\mathbf{- 0 . 3 9}$ & -0.16 & $\mathbf{- 0 . 3 4}$ & +0.27 \\
$\mathrm{~N}-\mathrm{NO}_{3}{ }^{-}$ & $\mathbf{0 . 3 2}$ & +0.24 & $\mathbf{+ 0 . 4 2}$ & -0.15 \\
$\mathrm{~N}-\mathrm{NH}_{4}{ }^{+}$ & $+\mathbf{0 . 3 6}$ & +0.14 & $\mathbf{+ 0 . 4 0}$ & -0.20 \\
$\mathrm{TN}$ & $\mathbf{+ 0 . 3 5}$ & -0.28 & $\mathbf{+ 0 . 3 0}$ & -0.18 \\
$\mathrm{TP}$ & -0.07 & $\mathbf{- 0 . 4 3}$ & $\mathbf{+ 0 . 3 7}$ & +0.15 \\
$\mathrm{GIGC}$ & +0.19 & $\mathbf{+ 0 . 4 8}$ & +0.17 & +0.29 \\
GIM & -0.23 & +0.16 & $\mathbf{+ 0 . 3 3}$ & $\mathbf{+ 0 . 3 3}$ \\
GIC & $\mathbf{- 0 . 3 8}$ & +0.24 & $\mathbf{+ 0 . 3 4}$ & +0.29 \\
\hline Variance explained (\%) & 50.68 & 27.54 & 47.45 & 32.87 \\
\hline
\end{tabular}

For the subsurface waters, positive variables were observed and, then, related to each other: $\mathrm{N}-\mathrm{NH}_{4}{ }^{+}(+0.36), \mathrm{TN}(+0.35), \mathrm{T}(+0.35)$ and $\mathrm{N}-\mathrm{NO}_{3}{ }^{-}(+0.32)$ contrasting with $\mathrm{DO}(-0.39)$, GIC (-0.38) and $\mathrm{pH}(-0.34) . \mathrm{EC}, \mathrm{pH}$ and DO saturation capacity are the physicochemical factors that follow the temperature trend (Mariani and Pompêo, 2008). The species $L$. sativum presented a low correlation value $(+0.19)$, and it was the only species of seed to be presented here that is directly influenced by the nitrogen cycle. Although eutrophication is intensified by the excess of nutrients (Jeppesen et al., 2017), especially of TP and TN, the PC1 of subsurface waters was not representative for the TP (-0.07), and the TN can act as a limiting factor in the germination of seeds. Still referring to the subsurface waters, in PC2, it can be noted that the EC $(+0.53)$ and the GIGC $(+0.48)$ are positively correlated with each other, contrasting with the PT (-0.43).

Coelho et al. (2020), in their study in the same reservoir, found a relationship between TP, EC and GI with the species S. alba, corroborating with this study in the seeds of S. alba, 
and indicating the same relationship in the species $C$. sativus and L. sativum. In the bottom waters, the PC1 resulted in $\mathrm{N}^{-\mathrm{NO}_{3}}{ }^{-}(+0.42), \mathrm{N}-\mathrm{NH}_{4}{ }^{+}(+0.40)$, TP $(+0.37), \mathrm{GIC}(+0.34)$, GIM $(+0.33)$ and also related the TN $(+0.30)$ with each other, opposing it to the DO variable (0.34). These relationships indicated that the species of C. sativus and S. alba had more representative values when the availability of the TP nutrient increased. The PC2 presented the scores of $\mathrm{pH}(+0.51), \mathrm{GIM}(+0.33)$, and $\mathrm{T}(-0.51)$, indicating an inversely proportional relationship regarding $\mathrm{pH}$ and $\mathrm{T}$. The $\mathrm{T}$ values were maintained in this study because they influence the environmental variables, however, they were not related to the $\% \mathrm{Gl}$ of the seed species, since the phytotoxicological tests were performed in a stable $T\left(20 \pm 2{ }^{\circ} \mathrm{C}\right)$ and not with those found in the field.

\section{Conclusion}

Water and sediment monitoring programs are the basis for making decisions, aiming to ensure the sustainability of the ecosystems. In this study, a few seeds were used as a parameter for the quality of the under surface and deep water of the Rio Grande reservoir, which was analysed from the toxicity tests, returning the following propositions: the GI (\%) of the seeds presented toxicity in a few points, and majorly boosted the germination of the seeds. The $L$. sativum species reported a more sensitive response to toxicity when compared to other seed species and it has the lowest degree of data dispersion, which was indicated by the standard deviation. In the under-surface waters, the TN values are higher than allowed by law (CONAMA 357/2005, Brasil, 2005), as well as the TP values in the deep waters. The germination of the $L$. sativum seeds performed a positive relationship with $\mathrm{N}-\mathrm{NH}_{4}{ }^{+}, \mathrm{N}-$ $\mathrm{NO}_{3}{ }^{-}$and $\mathrm{TN}$ in the under-surface waters and in the deep waters. It is concluded that the seed species have premises that can be adopted as a parameter of water quality, since they offer valuable information for the purposes of water management and risk assessment; highlighting, however, that more studies are required regarding the seed species represented here, along with a long-term monitoring to confirm that the results obtained in this study represent a consistent pattern. 


\section{Acknowledgments}

We thank the São Paulo State Research Support Foundation - FAPESP (Process: 17/10355-1) for technical training scholarships (Process: 2017/19001-8; 2018/20417-7; 2019/23767-1); the Coordination for the Improvement of Higher Education Personnel CAPES; the Laboratory for Environmental Analysis; and the Laboratory for the Characterization of Environmental Matrices at the Federal University of $A B C$ - UFABC.

\section{References}

AMERICAN PUBLIC HEALTH ASSOCIATION. Standard Methods for Examination of Water and Wastewater. 25 $5^{\text {th }}$ edition. Washington (EUA): APHA; 2005.

AMERICAN SOCIETY FOR TESTING AND MATERIALS. Standard guide for collection, storage, characterization, and manipulation of sediments for toxicological testing. ASTM/E 1391-94. Pensilvânia (EUA): ASTM; 1994.

AMERICAN SOCIETY FOR TESTING AND MATERIALS. Standard guide for conducting static acute toxicity tests with echinoid embryos. ASTM/ E 1563-95. Pensilvânia (EUA): ASTM; 1995.

AMERICAN SOCIETY FOR TESTING AND MATERIALS. Elements in water by ICP-MS. ASTM D5673/96. Pensilvânia (EUA): ASTM; 1996.

AMERICAN SOCIETY FOR TESTING AND MATERIALS. Measuring the toxicity of sedimentassociated contaminants with freshwater invertebrates. ASTM/E 1706-00. Pensilvânia (EUA): ASTM; 2000.

BARBIERI, E.; MARQUES, H. L. A.; BONDIOLI, A. C. V.; CAMPOLIM, M. B.; FERRARINI, A. T. Concentrações do nitrogênio amoniacal, nitrito e nitrato em áreas de engorda de ostras no município de Cananéia - SP. O Mundo da Saúde. 2014; 38 (1): 105-115.

BARBOSA, R. M.; GALTER, I. N.; PEREIRA, C. L.; MARTINS, L. A. R.; SILVA, K. S.; ANDRADEVIEIRA, L. F. Eficiência do pepino como modelo em bioensaios de fitotoxicidade. I Congresso Internacional de Ciências Biológicas, II Congresso Nacional de Ciências Biológicas, VI Simpósio de Ciências Biológicas; 2013 november 11-14; Pernambuco; BR.

BEGHELLI, F. G. S.; ROSA, A. H.; NISHIMURA, P. Y.; MEIRINHO, P. A.; LEONARDI, B. F.; GUIDUCE, F. S.; et al. Aplicações de sulfato de cobre no reservatório Guarapiranga, SP: distribuição no meio e efeitos sobre a comunidade planctônica. In: Instituto de Biociências, editor. Ecologia de reservatórios e interfaces. São Paulo; 2015. p. 460. 
Belo SRS. Avaliação de fitotoxicidade através de Lepidium sativum no âmbito de processos de compostagem [dissertation]. Coimbra: Faculdade de Ciências e Tecnologia/UC; 2011. 68 p.

BOSTELMANN, E. Avaliação da concentração de metais em amostras de sedimento do reservatório Billings, Braço Rio Grande, São Paulo, Brasil [dissertation]. São Paulo: Instituto de Pesquisas Energéticas e Nucleares/USP; 2006. 130 p.

BRASIL. Conselho Nacional do Meio Ambiente. Resolução No 344/04 - Estabelece as diretrizes gerais e os procedimentos mínimos para a avaliação do material a ser dragado em águas jurisdicionais brasileiras, e dá outras providências. Brasil: CONAMA; 2004.

BRASIL. Conselho Nacional do Meio Ambiente. Resolução No 357/05 - Classificação dos corpos de água e diretrizes ambientais para o seu enquadramento, bem como estabelece as condições e padrões de lançamento de efluentes, e dá outras providências. Brasil: CONAMA; 2005.

BRASIL. Ministério da Agricultura, Pecuária e Abastecimento; Regras para análise de sementes. Brasília (Brasil): Ministério da Agricultura, Pecuária e Abastecimento; 2009.

BRASIL. Ministério de Saúde; Secretaria de Vigilância em Saúde. Cianobactérias/cianotoxinas: procedimentos de coleta, preservação e análise. Brasília (Brasil): Ministério da Saúde; 2015.

BRITO, JR A. N. Modelagem dos fluxos de ressuspensão de sedimentos de um lago raso subtropical. [dissertation]. Alagoas: Universidade Federal de Alagoas; 2015. 31 p.

BURGOS, M.; SIERRA, A.; ORTEGA, T.; FORJA, J. M. Anthropogenic effects on greenhouse gas $\left(\mathrm{CH}_{4}\right.$ and $\left.\mathrm{N}_{2} \mathrm{O}\right)$ emissions in the Guadalete River Estuary (SW Spain). Science of the Total Environment. 2015; 503-504 (X): 179-189.

CAPOBIANCO, J. P. R.; WHATELY, M. Billings 2000: ameaças e perspectivas para o maior reservatório de água da região metropolitana de São Paulo. In: Instituto Socioambiental, editor. Relatório do diagnóstico socioambiental participativo da bacia hidrográfica da Billings no período 1989-99. São Paulo; 2002. p. 60.

CERVI, E. C.; HUDSON, M.; RENTSCHLER, A.; BURTON JR, G. A. Metal toxicity during shortterm sediment resuspension and redeposition in a tropical reservoir. Environmental Toxicology and Chemistry. 2019; 38 (7): 1476-1485.

COELHO, L. H. G.; JESUS, T. A.; KOHATSU, M. Y.; POCCIA, G. T.; CHICAROLLI, V.; HELWIG, K.; et al. Estrogenic Hormones in São Paulo Waters (Brazil) and Their Relationship with Environmental Variables and Sinapis alba Phytotoxicity. Water Air Soil Pollut. 2020; 231 (4): 150-169.

COMPANHIA AMBIENTAL DO ESTADO DE SÃO PAULO. Ensaios ecotoxicológicos com organismos aquáticos: Atendimento à legislação Ambiental - Orientações para realização de 
ensaios e apresentação dos resultados nos documentos encaminhados à CETESB. São Paulo (Brasil): CETESB; 2017.

COMPANHIA DE SANEAMENTO BÁSICO DO ESTADO DE SÃO PAULO [Internet]. São Paulo [cited 2020 jul 28]. Dados dos Sistemas Produtores. Available from: http://mananciais.sabesp.com.br/HistoricoSistemas?Sistemald =5.

CRUZ, J. M.; LOPES, P. R. M.; MONTAGNOLLI, R. N.; TAMADA, I. S.; SILVA, N. M. M. G.; BIDOIA, E. D. Phytotoxicity of Soil Contaminated with Petroleum Derivatives and biodiesel. Ecotoxicology and Environmental Contamination. 2013; 8 (1): 49-54.

CUNHA, D. G. F.; CALIJURI, M. C.; LAMPARELLI, M. C. A Trophic State Index for Tropical/subtropical Reservoirs (TSItsr). Ecological Engineering. 2013; 60 (X): 126-134.

DOEDERER, K.; GALE, D.; KELLER, J. Effective removal of MIB and geosmin using MBBR for drinking water treatment. Water Research. 2019; 149 (X): 440-447.

EMAMI, S.; POURBABAEI, A. A.; ALIKHANI, H. A. Interactive effect of nitrogen fertilizer and hydrocarbon pollution on soil biological indicators. Environmental Earth Sciences. 2014; 72 (9): 3513-3519.

ENVIRONMENT CANADA. Biological test method: Acute lethality using Daphnia spp. Report EPS 1/RM/11. Canada; 1990a.

ENVIRONMENT CANADA. Biological test method: Acute lethality test using rainbow trout. Report EPS 1/RM/9. Canada; 1990b.

ENVIRONMENT CANADA. Biological test method: Acute lethality test using threespine stickleback (Gasterosteus aculeatus). Report EPS 1/RM/10. Canada; 1990c.

ENVIRONMENT CANADA. Biological test method: Growth inhibition test using the freshwater alga Selenastrum capricornutum. Report EPS 1/RM/25. Canada; 1992a.

ENVIRONMENT CANADA. Biological test method: Fertilization assay using echinoids (sea urchin and sand dollars). Report EPS 1/RM/27. Canada; 1992b.

ENVIRONMENT CANADA. Biological test method: Test of larval growth and survival using fathead minnows. Report EPS 1/RM/22. Canada; 1992c.

ENVIRONMENT CANADA. Biological test method: Test of reproduction and survival using cladoceran Ceriodaphnia dubia.Canada. Report EPS 1/RM/21. Canada; 1992d.

ENVIRONMENT CANADA. Biological test method: Toxicity test using early life stages of salmonid fish (rainbow trout, coho salmon, or atlantic salmon). Report EPS 1/RM/28. Canada; $1992 \mathrm{e}$. 
ENVIRONMENT CANADA. Biological test method: Acute test for sediment toxicity using marine or estuarine amphipods. Report EPS 1/RM/26. Canada; $1992 f$

ENVIRONMENT CANADA. Biological test using luminescent bacteria (Photobacterium phosphoreum). Report EPS 1/RM/24. Canada; 1992g.

ENVIRONMENT CANADA. A framework for ecological risk assessment of contaminated sites in Canada: review and recommendations. Gaudet, C., Scientific Series n 199. Canada; 1994a

ENVIRONMENT CANADA. Guidance document on collection and preparation of sediments for physicochemical characterization and biological testing. EPS 1/RM/29. Ontario (Canada); 1994b.

ENVIRONMENT CANADA. Canadian Sediment Quality Guidelines for the Protection of Aquatic Life. Summary Tables. Canada; 1999.

FANTIN, A. C. M.; FREITAS, D. P. C.; FAGNANI, G. F.; LAPA, T. C. M. A. Teste de sensibilidade em sementes de Rúcula (Eruca sativa) e Alface (Lactuca $s p$ ) em contato com diferentes concentrações do pesticida Glifosato. Centro Superior de Educação Tecnológica/UNICAMP; 2009.

FRANKLIN, R. L. Determinação de mercúrio total e orgânico e avaliação dos processos de metilação e desmetilação em sedimentos do reservatório Rio Grande, Estado de São Paulo [dissertation]. São Paulo: Instituto de Pesquisas Energéticas e Nucleares/USP; 2010. 158 p.

FRANKLIN, R. L.; FÁVARO, D. I. T.; DAMATTO, S. R. Trace metal and rare Earth elements in a sediment profile from the Rio Grande reservoir, São Paulo, Brazil - determination of anthropogenic contamination, dating and sedimentation rates. Journal of Radioanalytical and Nuclear Chemistry. 2015; 307 (X): 99-110.

HERMES, L. C.; SILVA, A. S. Parâmetros básicos de avaliação de qualidade de água: significância ambiental. In: Embrapa, editor. Avaliação da Qualidade das Águas: Manual prático. Brasília; 2004. p. 55.

JEPPESEN, E.; SONDERGAARD, M.; LIU, Z. Lake Restoration and Management in a Climate Change Perspective: An Introduction. Water. 2017; 9 (2): 122-130.

KINDLEIN, C. P. Determinação do teor de nitratos e nitritos na água de abastecimento do município de Nova Santa Rita [monography]. Canoas: Centro Universitário La Salle; 2010.

KOHATSU, M. Y.; JESUS, T. A.; COELHO, L. H. G.; PEIXOTO, D. C.; POCCIA, G. T.; HUNTER, C. Fitotoxicidade de água superficial da Região Metropolitana de São Paulo utilizando bioensaio com Sinapis alba. Acta Brasiliensis. 2018; 2 (2): 58-62.

LAPA, M. P. Avaliação Ecotoxicológica de Solos Impactados com Borra Oleosa Submetidos a Diferentes Tratamentos de Biorremediação [monography]. Pelotas: Departamento de Engenharia Ambiental e Sanitária/UFPel; 2014. 
VIEIRA, L. M. Contaminantes prioritários e emergentes e o saneamento ambiental [monography]. Uberlândia: Faculdade de Engenharia Química/UFU; 2017.

LÓPEZ-DOVAL, J. C.; MONTAGNER, C. C.; ALBUQUERQUE, A. F.; MOSCHINI-CARLOS, V.; UMBUZEIRO, G.; POMPÊO, M. Nutrients, emerging pollutants and pesticides in a tropical urban reservoir: Spatial distributions and risk assessment. Science of The Total Environment. 2017; 575 (X): 1307-1324.

MAIA, A. A. D.; CARVALHO, S. L.; CARVALHO, F. T. Comparação de dois índices e determinação do grau de trofia nas águas do Baixo Rio São José dos Dourados, São Paulo, Brasil. Engenharia Sanitária e Ambiental. 2015: 20 (4): 613-622.

MARIANI, C. F.; POMPÊO, M. L. M. Potentially bioavailable metals in sediment from a tropical polymictic environment - Rio Grande Reservoir, Brazil. Journal of Soils and Sediments. 2008; 8 (5): $284-288$.

MATSUBARA, M. E.; HELWIG, K.; HUNTER, C.; ROBERTS, J.; SUBTIL, E. L.; COELHO, L. H. G. Amoxicillin removal by pre-denitrification membrane bioreactor (A/OMBR): Performance evaluation, degradation by-products, and antibiotic resistant bactéria. Ecotoxicology and Environmental Safety. 2020; 192 (X) 110258.

MEERSSCHE, E. V.; PINCKNEY, J. L. Nutrient Loading Impacts on Estuarine Phytoplankton Size and Community Composition: Community-Based Indicators of Eutrophication. Estuaries and Coasts. 2019; 42 (2): 504-512.

MENDES, P. M.; NETO, J. C. P.; GONÇALVEZ, L. B.; MACEDO, S. C.; ARAÚJO, T. R.; RODRIGUES, A. L.; et al. Improvement of the phytotoxicological test with lettuce seed germination: reliability and accuracy of the method. Brazilian Journal of Development. 2020; 6 (4): 1817818184.

ORGANIZAÇÃO PARA A COOPERAÇÃO E DESENVOLVIMENTO ECONÔMICO. Test N 202: Daphnia sp. Acute Immobilisation Test, OECD Guidelines for the Testing of Chemicals, Section 2, OECD Publishing. Paris; 2004.

ONTARIO MINISTRY OF ENVIRONMENT; Environment Ontario. Laboratory sediment biological testing protocol. Ontario (Canada): Ontario Ministry of Environment; 1992.

OVSYANNIKOVA, I. V.; PRYANICHNIKOVA, V. V. The Assessment of the Reservoir Water Phytotoxicity. IOP Conference Series: Earth and Environmental Science. 2019; 272 (2): 1-4.

PADOVESI-FONSECA, C.; PHILOMENO, M. G. Effects of algicide (copper sulfate) application on short-term fluctuations of phytoplankton in Lake Paranoá, Central Brazil. Brazilian Journal of Biology. 2004; 64 (4): 819-826. 
PAULA, V. C. S. Avaliação da fitotoxicidade e ecotoxicidade do extrato bruto de Microcystis aeruginosa [monography]. Curitiba: Universidade Tecnológica Federal do Paraná; 2016.

PICKETT, S. T. A.; CADENASSO, M. L.; GROVE, J. M.; BOONE, C. G.; GROFFMAN, P. M.; IRWIN, E.; et al. Urban ecological systems: Scientific foundations and a decade of progress. Journal of Environmental Management. 2011; 92 (3): 331-362.

PEDUTO, T. A. G.; JESUS, T. A.; KOHATSU, M. Y. Sensibilidade de diferentes sementes em ensaio de fitotoxicidade. Revista Brasileira de Ciência, Tecnologia e Inovação. 2019; 4 (2): 200-212.

POMPÊO, M. O Controle da Flora e Fauna Aquáticas pela Resolução CONAMA 467: Considerações Sobre a Normativa Brasileira. Revista do Departamento de Geografia. 2017; $33(X): 24-35$.

PORTO, A. S.; BEZERRA, M. G. F.; FABIAN, F. A.; SANTOS, J. G. Fitotoxicidade por nanopartículas de Cobre e Zinco para diferentes tratamentos na germinação de sementes de Lactuca sativa. Natureza online. 2019; 17 (1): 32-40.

SÃO PAULO. Decreto Estadual No 10.755/77 - Dispõe sobre o enquadramento dos corpos de água receptores na classificação prevista no Decreto n 8.468 , de 8 de setembro de 1976, e dá providências correlatas. São Paulo (Brasil): Decreto Estadual; 1997.

SILVA, J. N.; MATTIOLO, S. R. Fitotoxicidade do dicromato de potássio $\left(\mathrm{K}_{2} \mathrm{CR}_{2} \mathrm{O}_{7}\right)$ em sementes de alface (Lactuca sativa). Centro Tecnológico da Marinha em São Paulo/CTMSP; 2011.

STUMM, W.; MORGAN, J. J. Aquatic chemistry: An introduction emphasizing chemical equilibria in natural waters. In: Wiley-Blackwell, editor. New York; 1981. p. 780.

TIQUIA, S. M. Reduction of compost phytotoxicity during the process of decomposition. Chemosphere. 2010; 79 (5): 506-512.

UNITED STATES ENVIRONMENTAL PROTECTION AGENCY \& ARMY CORPS OF ENGINEERS. Evaluation of dredged material proposed for ocean - testing manual, EPA - 503/8-91/001. Office of Water (WH-556F). Washington (EUA). USEPA; 1991.

UNITED STATES ENVIRONMENTAL PROTECTION AGENCY. Method 3051- Microwave Assisted Acid Digestion of Sediments, Sludges, Soils and Oils U.S. Environmental Protection Agency. Washington (EUA). USEPA; 1994a.

UNITED STATES ENVIRONMENTAL PROTECTION AGENCY. Test methods forevaluating solid waste physical/chemical methods (SW-846). Washington (EUA). USEPA; 1994b.

UNITED STATES ENVIRONMENTAL PROTECTION AGENCY. Methods for measuring the toxicity and bioacumulation of sediment-associated contaminants with freshwater invertebrates. EPA/600/R-1994/024. Washington (EUA). USEPA; 1994c. 
UNITED STATES ENVIRONMENTAL PROTECTION AGENCY. Methods for asssessing the toxicity of sediment-associated contaminants with estuarine and marine amphipods. U. S. Environmental Protection Agency. EPA 600/R-94/025. Washington (EUA). USEPA; 1994d.

UNITED STATES ENVIRONMENTAL PROTECTION AGENCY. Methods for measuring the toxicity and bioacumulation of sediment-associated contaminants with freshawater invertebrates. U. S. Environmental Protection Agency. EPA 600/R-94/024. Washington (EUA). USEPA; 1994e.

UNITED STATES ENVIRONMENTAL PROTECTION AGENCY. Purple urchin, Strogylocentrotus purpuratus and sand dollar, Dendraster excentricus; larval development test method. In: Short-term methods for estimating the chronic toxicity of effluents and receiving waters to west coast marine and estuarine organisms. EPA/600/R-95/136. Washington (EUA). USEPA; 1995.

UNITED STATES ENVIRONMENTAL PROTECTION AGENCY. The incidence and severity of sediment contamination in surface waters of the United States. Volume 1: National Sediment Quality Survey. U.S. Environmental Protection Agency. Office of Science and Technology Washington, DC., EPA 823-R-97-006. Washington (EUA). USEPA; 1997.

UNITED STATES ENVIRONMENTAL PROTECTION AGENCY. Protocols for short term toxicity screening of hazardous waste sites - 600/3-88/029. Washington (EUA). USEPA; 1989

WENGRAT, S. Avaliação das alterações da biodiversidade de diatomáceas recentes e pretéritas em reservatórios com diferentes estados tróficos (áreas de mananciais da RMSP e arredores, SP) [thesis]. São Paulo: Instituto de Botânica da Secretaria do Meio Ambiente; 2016. $137 \mathrm{p}$.

ZHANG, H.; MA, G.; SUN, L.; HUIYING, L. I. Effect of alkaline material on phytotoxicity and bioavailability of $\mathrm{Cu}, \mathrm{Cd}, \mathrm{Pb}$ and $\mathrm{Zn}$ in stabilized sewage sludge. Environmental Technology. 2018; 39 (17): 2168-2177.

ZOPPAS, F. M.; BERNARDES, A. M.; MENEGUZZI, A. Parâmetros operacionais na remoção biológica de nitrogênio de águas por nitrificação e desnitrificação simultânea. Revista Engenharia Sanitária e Ambiental. 2016; 21 (11): 29-42. 